\title{
The Threat of Destitution as a Deterrent against Asylum Seeking in the European Union
}

\author{
Sylvie Da Lomba
}

\begin{abstract}
The problematization of asylum has detrimentally impacted on the provision of support for asylum seekers in host countries. The threat of destitution has become instrumental in restrictive asylum policies and is increasingly used as a deterrent against asylum seeking. The EU experience reveals acute tensions between the EU asylum agenda and the EU Member States' obligations under international refugee and human rights law. The provision of support for asylum seekers challenges narrow approaches to the realization of socio-economic rights for "others" and to host countries' duties in that respect. The EU Reception Conditions Directive, which aims to set out standards for the reception of asylum seekers across the Union, exemplifies this predicament. Yet international refugee and human rights law provides a legal framework that establishes minimum standards critical to dignified living for asylum seekers and the protection of the right to seek refugee status in the EU and beyond.
\end{abstract}

\section{Résumé}

La problématique de l'asile a eu des répercussions nuisibles sur la disposition de l'aide aux demandeurs d'asile dans les pays d'accueil. La menace de la misère est devenue une pierre de touche des politiques conjoncturelles sur l'asile et elle sert de plus en plus d'élément dissuasif pour contrer la demande d'asile. L'expérience de l'Union européenne révèle des tensions aiguës entre le programme d'asile de l'UE et les obligations des pays membres de l'UE en regard des droits internationaux des réfugiés et de la personne. La disposition sur l'aide aux demandeurs d'asile remet en question les approches à court terme à l'égard de la mise en ouvre des droits socio-économiques pour les responsabilités des "étrangers " et des pays hôtes. Les directives sur les conditions d'accueil de l'UE, qui visent à établir des normes pour l'accueil de demandeurs d'asile partout dans l'Union, exemplifient cette difficile situation. Malgré tout, les droits internationaux des réfugiés et de la personne fournissent un cadre qui fixe des normes minimales de conditions de vie décentes pour les demandeurs d'asile et la protection du droit de demander un statut de réfugié dans l'UE et ailleurs.

\section{Introduction}

Actuellement des centaines de personnes venues chercher protection en France couchent dans la rue faute d'hébergement. Des femmes, des hommes, des enfants qui ont dû quitter leur pays où ils étaient persécutés ou risquaient de l'être sont contraints de vivre dans des conditions proches de la mendicité. ${ }^{1}$

7 his bleak picture is symptomatic of a deterioration of the conditions of the reception of asylum seekers not only in France, but across the European Union (EU). The treatment of asylum seekers pending adjudication on their application for refugee status reveals acute tensions between the hostile agenda of the EU and its Member States in the field of asylum and their humanitarian commitment and obligations. Negative perceptions of asylum seekers that foster myths and prejudice have polluted policy making and normative reform in the area of asylum at both national and European level. The threat of the "bogus" asylum seeker has emerged as a pervasive and recurrent theme in the political 
rhetoric. $^{2}$ Moreover, border control, immigration, and security concerns have become primary factors in the shaping of the EU asylum policy. ${ }^{3}$ Asylum is increasingly perceived as a migration-related matter closely connected with the question of irregular migration. ${ }^{4}$ The current context leads to a "quantitative approach" to asylum where "cutting down the numbers" becomes a paramount objective and a yardstick for measuring the efficiency of asylum laws and policies, thus progressively eroding the humanitarian institution of asylum. Portrayed as burdens for domestic economies as well as potential threats to national security, asylum seekers are becoming the EU "unwanted guests."

The paper examines how scant provisions for support of asylum seekers have become instrumental in restrictive asylum policies across the EU. In other words, it considers attempts to use the threat of destitution as a deterrent against asylum seeking. The paper focuses on asylum seekers, namely, persons who have applied for refugee status within the meaning of Article 1(A)(2) of the Convention relating to the Status of Refugees (Refugee Convention). ${ }^{5}$ The reasons for this focus are twofold: first, the Refugee Convention remains the cornerstone of refugee protection; second, the Convention has come under sustained attacks, making asylum seekers prime targets of harsher legislation on State support. ${ }^{6}$ However, it is acknowledged that many of the issues discussed in this paper are also relevant to other categories of people in need of international protection. ${ }^{7}$

The paper adopts a human rights approach to support for asylum seekers and looks at the question of socio-economic rights for asylum seekers in the context of the EU. For that purpose, the paper scrutinizes the international legal framework and the Council Directive laying down minimum standards for the reception of asylum seekers (Reception Conditions Directive) ${ }^{8}$ which is now central to the provision of support for asylum seekers in the EU. The challenges faced by host States and asylum seekers in relation to reception are also considered.

\section{Protecting the "Others" against Destitution: The Question of Fundamental Socio-economic Rights for Asylum Seekers}

Few will dispute that a person in abject condition, deprived of adequate means of subsistence, or denied the opportunity to work, suffers a profound affront to his sense of dignity and intrinsic worth. Economic and social arrangements cannot therefore be excluded from a consideration on the demands of dignity. At the least, it requires recognition of a minimal concept of distributive justice that would require satisfaction of the essential needs of everyone. ${ }^{9}$

Respect for human dignity supposes the fulfillment of basic socio-economic rights. Many of these rights may be described as droits créances, the implementation of which requires positive action on the part of the State and the mobilization of considerable State resources.

Socio-economic rights aim to provide a base of material security, inherent in human dignity, below which citizens shall not fall. ${ }^{10}$ The use of the word "citizen" is not neutral. Indeed, the realization of socio-economic rights for nonnationals is mediated by significant political, economic, and social factors. The conferment of socio-economic rights on non-nationals, namely "non-citizens," necessitates an approach to the welfare State based on greater social and economic solidarity. ${ }^{11}$

In that respect, two contradictory trends tend to dominate legislative debates and interventions: the need to achieve greater equality between nationals and non-nationals and the need to respond to social tensions, especially in times of economic recession when foreign migrants are perceived as a threat to the domestic workforce. Whilst the first trend supports the adoption of non-discriminatory laws and policies, the second results in stringent measures that are likely to contribute to the impoverishment of migrants. ${ }^{12}$

The question of basic socio-economic rights for asylum seekers is nested within wider debates on asylum and migration control as well as general discussions on the future of welfare provision. Whilst the latter are concerned with the pressures faced by the welfare State as a result of "economic globalisation, budgetary deficits, demographic change, as well as the effects of neo-liberal thinking on welfare provision," 13 the former focuses on the pressures-perceived or actual-stemming from forced and voluntary migration. Both types of pressure have significant implications for those seeking refugee status in the EU, including for their access to welfare provisions pending a final decision on their application for refugee status. The polarized dynamic that opposes citizens to non-citizens, "us" to "others," with respect to socio-economic rights is duplicated at EU level with its self-centred approach, which primarily seeks the entitlement of EU citizens. Whilst there is progress with regard to the rights and status of thirdcountry nationals who are permanent residents in the EU, ${ }^{14}$ the EU asylum and immigration policies show a trend towards the exclusion of other categories of non-EU citizens.

The dilemma of asylum seekers lies with their great vulnerability and high dependence on host States as well as the temporary and uncertain nature of their status. Restrictive asylum laws and policies exacerbate this vulnerability inherent in the condition of asylum seeker. In spite of their evident need for State support, the realization of socio-economic 
rights for asylum seekers in host countries remains the object of heated debates. Because they do not contribute to the economy in general and to the welfare system in particular, asylum seekers are too often perceived and portrayed as undeserving recipients of State benefits and assistance. ${ }^{15}$ Such views rest upon mistaken assumptions and prejudice against asylum seekers. No one can contest that asylum seekers are in great need of State support. And if the assertion that they benefit from rather than contribute to the host State welfare system is indeed correct, the latter statement must be put into context to avoid simplistic and erroneous conclusions. The reasons for asylum seekers' need for State support are entrenched in their very circumstances which make them one of the most vulnerable populations worldwide. Paradoxically, host States aggravate asylum seekers' dependence by preventing, limiting, or unnecessarily delaying their access to employment. Yet, as observed by UNHCR, "many asylumseekers are capable of attaining a certain degree of self-reliance if provided with an opportunity to do so." 16 This issue is examined later in the paper.

\section{The Challenges Faced by Host States and Asylum Seekers}

The most significant challenges faced by the EU Member States as host States relate to the costs associated with the reception of asylum seekers and the logistics of such reception. A further difficulty arises from anti-refugee sentiment which may be rife in host countries and encouraged by governments. Indeed, many governments bear much responsibility in perpetrating myths about asylum seekers and fostering prejudice. The growing politicization of asylum in the EU has exacerbated this trend to the detriment of asylum seekers' rights. Alarmist discourses on asylum abuse are indicative of this development. ${ }^{17}$ While it is accepted that abuses of asylum systems take place, the "threats" posed by so-called "bogus" asylum seekers-as opposed to "genuine" asylum seekers-have been exaggerated with a view to justifying stricter policies and legislation. ${ }^{18}$ The concept of "bogus" asylum seeker remains extremely vague as it is often ascribed prior to the substantive examination of asylum claims. The challenge for the EU Member States is to receive asylum seekers in dignified conditions whilst addressing the problem of misuse of asylum channels. ${ }^{19}$ The latter, however, should not be used as a pretext to legitimize a deterioration of reception conditions in the EU. A further difficulty lies with the fact that the provision of State assistance for asylum seekers is often "set against competing national priorities for limited resources." ${ }^{20}$ While the role of charities and NGOs in the provision of support to asylum seekers must not be underestimated, these organizations cannot offer a viable substitute for deficient State assistance. ${ }^{21}$ The ability of charities to address the demand for support was questioned in the UK High Court. ${ }^{22}$ Research carried out by the UK Refugee Council revealed that 85 per cent of respondents (132 charitable organizations) did not have funding to cover the cost of the services they provided to asylum seekers denied support under English law. ${ }^{23}$ The challenge for the EU is therefore to reconcile its asylum agenda with the Member States' humanitarian duties and obligations, whilst addressing the economic and practical difficulties arising from the reception of asylum seekers. In that respect, two observations may be made. First, without undermining the economic implications of support for asylum seekers, one must stress the fact that the EU Member States are amongst the wealthiest nations in the world and that the scale of the problems they experience as host countries cannot compare with the magnitude of those faced by much poorer host countries. Secondly, the EU as a whole must account for the economic disparities that exist within the enlarged Union and ensure that the States which have recently joined the EU are able to provide adequate reception conditions. ${ }^{24}$

As already observed, many asylum seekers are destitute upon arrival in host countries. They are, therefore, dependent on host countries for their essential living needs such as accommodation, food, clothing, and health care. "Unsympathetic" asylum laws and policies in the EU have impacted upon the extent and modalities of State assistance for asylum seekers. There is a perception amongst EU Member State Governments that generous provisions of support render them "too" attractive to asylum seekers. ${ }^{25}$ Further difficulties stem from the complexities associated with access to support by asylum seekers in host States. Effective access supposes that asylum seekers are made aware of their rights. Hence, the existence of and access to adequate information is the necessary corollary to efficient support provision. Restrictive approaches to reception conditions make prompt and comprehensive information even more vital as exemplified by UK legislation. Indeed, Section 55 of the much criticized Nationality, Immigration and Asylum Act 2002 (NIA Act 2002) stipulates that the Secretary of State for the Home Department (Secretary of State) and local authorities may refuse support where the former is not satisfied that "the claim was made as soon as reasonably practicable after the person's arrival in the UK." 26 Section 55 was the object of much controversy and litigation. ${ }^{27}$ From the day it entered into force, the words "as soon as reasonably practicable" were interpreted as meaning "immediately on arrival." 28 The deterrent nature and purpose of Section 55 were made obvious in a statement of Beverley Hughes, the then Immigration Minister: 
It is a reasonable expectation that desperate people fleeing for their lives will claim asylum as soon as they can and we will continue to support these people in the same way we do now. However, we are determined to tackle abuse and these measures send a clear signal across the world that the asylum system must be used for its proper purpose. It is not acceptable for people to claim asylum after being in the UK for weeks or months working illegally, simply as a way of staying on at the taxpayer's expense and delaying removal. ${ }^{29}$

The fact that asylum seekers may need specialized care and that some groups are particularly vulnerable render eligibility for and access to adequate support even more critical to dignified living in host countries, whilst presenting the latter with additional challenges and obligations. As stressed by UNHCR, there are groups of asylum seekers with special needs; this is the case of female asylum seekers, children seeking asylum, and elderly asylum seekers. ${ }^{30}$ These persons are particularly vulnerable when they are not accompanied by family members.

The question of reception conditions for asylum seekers poses challenges for both providers and recipients. A balance that accommodates asylum seekers' needs while accounting for host countries' resource capacity must be found. In the current context, however, the problematization of asylum has led to a deterioration of asylum seekers' standard of living in the EU Member States. Governments present stringent provisions on support as key tools in their fight against abuses of asylum procedures, thereby justifying and legitimizing such provisions. These harsh measures, however, serve a much wider agenda, namely the reduction of the numbers of asylum claims lodged within the EU Member States and at their borders. This quantitative and thus restrictive approach to asylum detrimentally impacts on the level of support available to asylum seekers. Support for asylum seekers, however, cannot be reduced to a humanitarian exercise depending on EU Member States' "generosity" and discretion. Indeed, international refugee law and international human rights law in particular provide a binding legal framework which sets out minimum standards applicable to the reception conditions of asylum seekers in the EU.

\section{The International Legal Framework}

The Refugee Convention is silent on the question of reception conditions for asylum seekers. It remains, however, that the right to seek refugee status that may be inferred from Article 1(A)(2) of the Refugee Convention cannot be fully realized in the absence of dignified living standards for those exercising the right in question. ${ }^{31}$ International human rights law plays a fundamental complementary role in de- fining minimum standards for the reception of asylum seekers. Indeed, the obligations arising from international human rights law are relevant to the treatment of asylum seekers and impose constraints on EU and Member State legislation. The provision of support for asylum seekers in the Union, however, shows dissension between the Member State Governments' perceived discretion and their obligations under international human rights law. This is symptomatic of wider tensions between the restrictive agenda of the EU and its Member States and international refugee and human rights law.

The minimum core of human rights applies to everyone in all situations. The Universal Declaration of Human Rights (UDHR) and the International Covenant on Economic, Social and Cultural rights (ICESCR) recognize the right to all individuals to an adequate standard of living, which includes the provision of food, clothing and accommodation $(\ldots) .^{32}$

Moreover both instruments protect the right to health care $^{33}$ as well as the right to education which is particularly relevant to children asylum seekers. ${ }^{34}$ The Convention on the Elimination of all Forms of Discrimination Against Women (CEDAW) ${ }^{35}$ and the Convention on the Rights of the Child (CRC) ${ }^{36}$ provide additional protection to particularly vulnerable groups of asylum seekers, namely, female and minor asylum seekers. However, three main factors mediate the extent to which these international instruments can contribute to shaping EU and Member States' legislation on the reception of asylum seekers and impose minimum standards in that respect. The first factor, namely the lack of binding effect, is specific to the UDHR. The second factor relates to the ICESCR and its mode of implementation, i.e. the progressive realization of the rights recognized in the Covenant to the "maximum of [the States'] available resources." 37 The third factor is connected with the implementation and enforcement weaknesses that characterize the international legal order.

The absence of effective supervisory mechanisms means that sanctions for States' failures to comply with international law are often of limited effect. In the international legal order, the State very much remains the 'champion' of individual rights. In practice, this means that where a State is unwilling or unable to perform [its] obligations, the individuals who fall within its jurisdiction will [often] be deprived of the benefit of the rights conferred by international law $(\ldots) .^{38}$

A human right central to the protection of asylum seekers is the prohibition of torture, cruel, inhuman and degrading treatment or punishment. This fundamental right 
is enshrined in a number of international instruments, including the $\mathrm{UDHR}^{39}$ and the International Covenant on Civil and Political Rights (ICCPR). ${ }^{40}$ The prohibition in question is also incorporated in the Convention for the Protection of Human Rights and Fundamental Freedoms (ECHR). ${ }^{41}$ This Convention, which is binding on all EU Member States, is crucial to the protection of human rights in Europe. Article 1 of the ECHR provides that " $[\mathrm{t}]$ he High Contracting Parties shall secure to everyone within their jurisdiction the rights and freedoms defined in Section I of this Convention." Consequently, the benefit of the ECHR provisions extends to asylum seekers who find themselves within the jurisdiction of the EU Member States. The relevance of the ECHR, and of Article 3 in particular, to the reception standards applicable to asylum seekers was evinced in the case law on Section 55 of the NIA Act 2002.42 As already noted, Section 55(1) permits the UK Secretary of State and local authorities to refuse support where the Secretary of State is not satisfied that "the claim was made as soon as reasonably practicable after the person's arrival in the United Kingdom." Section 55, which was inserted as a very late amendment in the Nationality, Immigration and Asylum Bill, aims to ensure that people apply for asylum as soon as possible. Lord Filkin observed: "There is clearly an issue about whether people should be supported by the state while they make an asylum claim which, on all the evidence, appears to be substantially late." 43 As mentioned above, the UK Government was prompt to adopt a harsh approach and read the words "as soon as reasonably practicable" as meaning "immediately on arrival." 44 "A significant number of single asylum seekers and couples without children $\left[{ }^{45}\right]$ were deprived of support and, as a result, a high profile and successful challenge to refusal of support was lodged, claiming breaches of the ECHR: R. ( $Q$ and others) v. Secretary of State for the Home Department $\left[{ }^{46}\right][R .(Q$ and others $)] . " 47$

Section 55 of the NIA Act 2002 turned the question of support for asylum seekers in the UK into a battleground between the judiciary and the executive. In $R$. ( $Q$ and others), the Home Secretary sought to challenge the judgment of Collins J. in the High Court. ${ }^{48}$ Collins J. held that Section 55 contravened Article 3 of the ECHR. ${ }^{49}$ Article 3 reads that: "No one shall be subjected to torture or to inhuman or degrading treatment or punishment." On March 18, 2003, the Court of Appeal upheld the judgment of Collins J. Firstly, the Court of Appeal recalled that the concept of treatment within the meaning of Article 3 of the ECHR required a positive action on the part of the State. ${ }^{50}$ The Court found that the fact that asylum seekers were prohibited from working ${ }^{51}$ together with the fact that they were no longer entitled to support if destitute amounted to positive action on the part of the UK Government. ${ }^{52}$ Secondly, the Court of Appeal observed that the level of degradation necessary to breach Article 3 fell "significantly below" the definition of destitution contained in the Immigration and Asylum Act 1999. ${ }^{53}$ To be found "destitute" under the Act, an asylum seeker must have been or must be unable to obtain adequate accommodation, food, and other essential items. ${ }^{54}$ In Pretty v. UK, the European Court of Human Rights provided guidance as to the level of suffering, physical or mental, required to engage Article $3 .{ }^{55}$ The Court held:

As regards the types of 'treatment' which fall within the scope of Article 3 of the Convention, the Court's case law refers to 'ill-treatment' that attains a minimum level of severity and involves actual bodily injury or intense physical or mental suffering. Where treatment humiliates or debases an individual showing lack of respect for, or diminishing, his or her human dignity or arouses feelings of fear, anguish or inferiority capable of breaking an individual's moral and physical resistance, it may be characterised as degrading and also fall within the prohibition of Article 3. The suffering which flows from naturally occurring illness, physical or mental, may be covered by Article 3 , where it is, or risks being, exacerbated by treatment, whether flowing from conditions of detention, expulsion or other measures, for which the authorities can be held responsible. ${ }^{56}$

In the High Court, Collins J. took the view that “ (. . .) unless other means of support are available when support is withdrawn, there will be a breach of Article 3 [of the ECHR]." 57 The Court of Appeal, however, adopted a narrower approach to breaches of Article 3 and ruled that the mere fact that there was a "real risk" that asylum seekers' conditions could "verge on" the degree of severity described in Pretty was not in itself sufficient to trigger a breach of Article 3 of the ECHR. ${ }^{58}$ In contrast with Collins J., the Court of Appeal held that it was not unlawful for the Secretary of State to decline support "unless and until" it was clear that charitable support was not available and that the asylum seeker could not fend for himself or herself,59 the burden of proof being on the asylum seeker. ${ }^{60}$ In the absence of other sources of support, however, a State's refusal to provide support could amount to treatment contrary to Article 3 of the ECHR where the asylum seeker's condition is so severe as to meet the threshold set out in Pretty. ${ }^{61}$

Compliance with Articles 8(1) (right to respect for private and family life) and 6 (right to a fair trial) of the ECHR was also considered in $R$. ( $Q$ and others). Collins J. took the view that Section 55 entailed a "real risk" to leave asylum seekers destitute in breach of both Articles 3 and 8(1) as 
"[he was] not persuaded that charity offer[ed] a real chance of providing support." 62 It follows from the case law of the European Court of Human Rights that, whilst not every act or measure which adversely affects moral or physical integrity will interfere with the rights protected in Article 8(1), treatment which does not reach the degree of severity required under Article 3 can nonetheless infringe Article $8(1) .{ }^{63}$ The Court of Appeal, however, did not think it necessary to consider Article 8(1) because it "add[ed] little." 64 Moreover, on the facts of the case, it was "easier [to] envisage the risk of infringement of Article 3 rights rather than of article 8 rights." 65 "That said, [the Court of Appeal] accepted that if the denial of support impacted sufficiently on the asylum seeker's private and family life, including on his or her physical or mental integrity and autonomy, there would be a breach of Art. 8(1) (unless justified under Art. $8(2)\left[{ }^{66}\right] . "{ }^{\prime} 77$ Both the High Court and the Court of Appeal went on to consider Article 6 of the ECHR. The Court of Appeal agreed with Collins J. who found that the process as a whole did not satisfy the requirements of Article $6 .^{68}$ The Court of Appeal concluded that the system for assessing asylum seekers' eligibility for support under Section 55 was unfair and the assessment process flawed. ${ }^{69}$ Following the decision of the Court of Appeal, the Home Secretary indicated that the procedural flows identified by the courts would be rectified. Still decisions made by the Secretary of State under Section 55 continued to be challenged. The grounds of challenge concerned the timing of the applications for support and alleged breaches of Article 3 of the ECHR. With regard to the first point, Maurice Kay J. found that the conclusion reached by the Secretary of State was justified in two cases out of three. Whilst the Home Secretary's decisions were justifiable in the case of " $S$ " and " $T$ ", the decision process was deemed unfair and lacking rationality in the case of " $D$ ". ${ }^{70}$ Turning to the human rights aspects, Maurice Kay J. found that Article 3 of the ECHR had been engaged in all three cases.

All three applicants were in a very distressed state: " $S$ " was forced to beg for food, and suffered from psychological disturbance and significant weight loss; " $D$ " had also begged for food, was sleeping rough, and felt hungry, frightened and depressed; " $T$ " had lived at Heathrow, where he found it difficult to sleep due to noise and light and was unable to bathe or wash his clothes; he developed a cough and a problem with one eye, and began to feel increasingly demoralised and humiliated. ${ }^{71}$

On May 21, 2004, the Court of Appeal dismissed three appeals lodged by the Home Secretary against rulings in the High Court and agreed with the latter that Article 3 of the ECHR had been violated in the case of three destitute asylum seekers. ${ }^{72}$ Although the UK Government declared that it would yet again revise the way Section 55 was implemented so that it would operate more humanely, it pointed out that it would consider challenging the ruling of the Court of Appeal in the House of Lords. The UK Refugee Council's Executive, Maeve Sherlock, warned against this:

We welcome the decision to change how this policy, known as Section 55, operates. The Court of Appeal ruling found the policy of denying food and shelter to asylum seekers was unlawful, as they would have no other means of support. Fighting that ruling through higher courts is bound to be costly and long drawn out. We urge ministers not to pursue that course, but instead follow the logic of this change of approach, which will ensure asylum seekers have the basic essentials with which to live.

There is clear evidence that Section 55 is causing widespread misery and destitution among people who have fled persecution in their own countries and deserve protection here. It is administratively cumbersome, which wastes valuable Home Office time that could be better spent on making high quality asylum decisions. $^{73}$

It is believed that the question of support for asylum seekers under Section 55 of the NIA Act 2002 will continue to be a source of tensions between the UK judiciary and the UK Government and reveal inconsistencies between domestic provisions and human rights standards.

A further instrument to consider is the Charter of Fundamental Rights of the EU (EU Charter). ${ }^{74}$ In addition to the right to asylum, ${ }^{75}$ the EU Charter protects a number of rights that may contribute to improving the reception conditions of asylum seekers across the EU. These include the right to social security and social assistance, ${ }^{76}$ access to preventive health care and medical treatment, ${ }^{77}$ education, ${ }^{78}$ and the right of children to "such protection and care as is necessary for their well-being." 79 For the time being, the lack of binding effect of the EU Charter constricts the influence it may have in shaping EU policy and legislation on asylum. Yet, as noted by Rogers, the EU Charter has been "taking hold in certain quarters by stealth, winning friends and influencing people. It is gathering a momentum of its own, not just in academic circles," and "[i]ts practical effects both actual and potential, can no longer be ignored." 80 This is certainly the case in the field of asylum where " $[n]$ ot only does it reinforces the rights-based nature of asylum and migration law, but it also provides a useful interpretative force." ${ }^{81}$ Importantly, the EU Constitution, signed on October 29, 2004, renders the EU charter binding. ${ }^{82}$ 
International human rights law provides a legal framework within which reception standards for asylum seekers must be defined. However, as exemplified by the UK experience, compliance with human rights obligations has become problematic in the context of restrictive asylum laws and policies. At the time when the EU is moving towards a common European asylum system, it is imperative that international standards are endorsed by the EU and its Member States if the right to seek refugee status is to be safeguarded in the Union.

\section{The Reception Conditions Directive}

At the Tampere European Council of October 15 and 16, 1999, the EU Member States agreed to establish a set of common basic rules and principles establishing a common European asylum system against the background of a common asylum and immigration policy. ${ }^{83}$

This system should include, in the short term, a clear and workable determination of the State responsible for the examination of an asylum application, common standards for a fair and efficient asylum procedure, common minimum conditions for the reception of asylum seekers, ${ }^{84}$ and the approximation of rules on the recognition and content of refugee status $(\ldots) .{ }^{85}$

On January 27, 2003, the Council of the EU adopted the Directive laying down minimum standards for the reception of asylum seekers (Reception Conditions Directive). ${ }^{86}$ The Reception Conditions Directive was the outcome of a polarized and heated debate where the need to ensure respect for human dignity was balanced against the overall restrictive objectives of the EU asylum policy as well as financial considerations. Whilst concern for fundamental human rights encouraged the adoption of more generous standards protective of human dignity, the drive towards reducing asylum seeking in the Union called for the levelling down of these standards. It was unavoidable that these tensions would impact on the Directive provisions. The Reception Conditions Directive gives the Member States considerable latitude with respect to its implementation. ${ }^{87}$ Whilst UNHCR welcomed the Directive as "an important step in bringing greater coherence to asylum policy in the European Union," it regretted the overall lack of harmonization and "would like to have seen more safeguards in certain areas." 88

Because of the tensions and discord that marked the drafting and decision-making process, the Reception Conditions Directive was unable to reflect best practice. ${ }^{89}$ Notwithstanding the existence of constraints arising from international refugee and human rights law, the policy objectives of the EU in the field of asylum shaped the
Directive and supported lower reception standards. In the opinion of many Member States, the adoption of more generous provisions carried the risk of encouraging asylum seeking in the EU, thus defeating the policy objective of deterrence..$^{90}$ One could attempt to argue that the possibility offered to Member States to retain or introduce more favourable provisions ${ }^{91}$ renders the adoption of lower standards more acceptable. This line of reasoning, however, cannot be reconciled with the Member States' perception that more liberal domestic provisions will make them more "attractive" to asylum seekers. ${ }^{92}$ This belief will dissuade many Member States from maintaining more generous domestic laws and practices. Consequently the minimum standards set out in the Directive are likely to become the standards common to the Member States.

Compliance with international refugee and human rights law required the adoption of standards conducive to dignified living conditions for asylum seekers in the EU. However, the compromises needed to overcome Member States' divergences together with conflicting human rights and policy objectives led to the watering down of the Commission's original Proposal for a Reception Conditions Directive. ${ }^{93}$ While there are positive aspects to the Directive, it is apparent from its provisions that lowest national standards are likely to become the norm throughout the EU. The perceived impact of disparities in national laws and practices on asylum seekers' primary and secondary movements within the EU may prompt Member States with more liberal provisions to lower their standards. It is argued that the Directive does not provide sufficient safeguards against the temptation to use the threat of destitution as a deterrent tool in the EU Member States. The prevalence of restrictive asylum policy objectives over human rights considerations appears at odds with the EU's proclaimed commitment to the protection of human rights that culminated with the adoption of its own Charter of Fundamental Rights (the EU Charter), ${ }^{94}$ thus revealing a certain degree of "schizophrenia" on the part of the EU and its Member States.

The Reception Conditions Directive applies to applications for refugee status lodged within a Member State or at its borders ${ }^{95}$ until a final decision is taken. ${ }^{96}$ Asylum seekers' family members are also entitled under the Directive provisions. ${ }^{97}$ However, the Council of the EU refused to depart from the western concept of nuclear family and confined the scope of the Directive to the spouse or unmarried partner of the asylum seeker and the minor children of the applicant or the couple so long as they are unmarried and dependent. ${ }^{98}$ This narrow definition of the term "family member" goes against the recommendation of UNHCR, which advocates a more inclusive approach. ${ }^{99}$ The Recep- 
tion Conditions Directive makes provision for groups with special needs. These include "minors, unaccompanied minors, disabled people, pregnant women, single parents with minor children and persons who have been subjected to torture, rape or other serious psychological, physical or sexual violence." ${ }^{100}$ Moreover, the wording of the Directive suggests that this is not an exhaustive list. ${ }^{101}$

Asylum seekers' eligibility for State support under the Directive may be subject to a condition of resource. Article 13(3) stipulates that: "Member States may make provision of all or some of the material reception conditions and health care subject to the condition that applicants do not have sufficient means to have a standard of living adequate for their health and to enable their subsistence." 102 The wording of the Directive leaves great discretion to the Member States. Indeed, the latter may decide that State support shall be means tested in part or in its entirety ${ }^{103}$ and require that asylum seekers contribute to the cost of their material reception conditions and health care when they have "sufficient resources." 104 Significantly, the Directive leaves to the Member States the task of defining the key notion of "sufficient resources." The loose wording of the Directive is therefore open to stringent national interpretations that may detrimentally impact on the level of support for asylum seekers across the EU.

Another source of concern arises from the Directive provisions on reduction and withdrawal of State support. The first set of circumstances covers situations where the asylum seeker

abandons the place of residence determined by the competent authority without informing it or, if requested, without permission, or does not comply with reporting duties or with requests to provide information or to appear for personal interviews concerning the asylum procedure during a reasonable period laid down in national law, or has already lodged an application in the same Member State. ${ }^{105}$

Member States are under the obligation to resume support in relation to those applicants who have been traced or have voluntarily reported to the competent authority. ${ }^{106}$ This safeguard, however, is undermined by Member States' discretion to reinstall reception conditions fully or partially. ${ }^{107}$ A particular cause for concern lies with the Member States' possibility of refusing support where an asylum seeker is deemed to have "sufficient resources" 108 or "where [he or she] has failed to demonstrate that the asylum claim was made as soon as reasonably practicable after arrival in that Member State." 109 The latter provision was inserted at the request of the UK Government, which had decided to introduce tougher national legislation on support for asy- lum seekers, and may prove highly contentious as exemplified by the UK experience. ${ }^{110}$ Indeed, this provision echoes Section 55 of the NIA Act 2002. ${ }^{111}$ The Directive provides for general safeguards and requires decisions for the reduction, withdrawal, or refusal of reception conditions to be taken individually, objectively, and impartially; moreover, reasons must be given. ${ }^{12}$ It also stipulates that "decisions shall be based on the particular situation of the person concerned, especially with regard to [more vulnerable groups] taking into account the principle of proportionality." 113 Finally, the Directive provides that negative decisions relating to benefits may be appealed according to the procedures laid down in national law. ${ }^{114}$ These safeguards, however, may not be sufficient to counter the detrimental effects of likely stringent national interpretations.

The high degree of discretion enjoyed by the Member States under the Reception Conditions Directive is evidenced in the provision on asylum seekers' access to employment. Indeed, it is for the Member States to decide "a period of time, starting from the date on which the application for asylum was lodged, during which an applicant shall not have access to the labour market." 115 Where a first-instance decision on the asylum claim has not been taken within one year, "Member States shall decide the conditions for granting access to the labour market," provided that the applicant is not responsible for this delay. ${ }^{116}$ The Directive, therefore, extends to one year the six-month period originally proposed by the Commission during which asylum seekers may be denied access to employment. ${ }^{117}$ Access to employment shall not be removed during appeals; this was a particularly contentious provision during the Council negotiations. ${ }^{118}$ The Directive allows for a certain degree of protectionism since Member States are allowed to give priority for access to domestic labour markets to EU citizens, nationals of States parties to the Agreement on the European Economic Area, and legally resident third-country nationals. ${ }^{119}$ UNHCR felt that

the decision not to harmonize the very different national policies and practices regarding access to employment is a drawback, particularly at a time when many states are talking about labour deficits and are also concerned about the costs of supporting asylum seekers through a sometimes lengthy asylum procedure. Not allowing asylum seekers-many of whom are talented and skilled professionals — to work is not beneficial to market economies."

Besides, the role that work can play in helping asylum seekers to regain some sense of normality and dignity should not be overlooked. ${ }^{121}$ 
Because the vast majority of asylum seekers are destitute upon arrival, material reception conditions must be provided "to ensure a standard of living adequate for the health of applicants and capable of ensuring their subsistence." 122 Hence, the modalities of State support for asylum seekers must be conducive to the creation of dignified living conditions in host States. Agreement on the forms that support could take proved problematic; as a result the Directive gives great discretion to the Member States. Indeed, Article 13(5) reads that material reception conditions may "be provided in kind, or in the form of financial allowances, or vouchers or in combination of these provisions." 123 In its Explanatory Memorandum, the Commission indicated that this system was "flexible enough to allow Member States to choose the way of providing material reception conditions that are most suitable according to their internal situation."124 Voucher schemes were criticized for stigmatizing asylum seekers, exposing them to prejudice and discrimination, and forcing them to live in a cashless society. ${ }^{125}$ In the UK, vouchers were replaced by cash allowances in April 2002 following claims that they stigmatized asylum seekers, posed practical difficulties, and were uneconomical. ${ }^{126}$

With respect to housing, the Directive gives Member States the choice between different types of accommodation, namely accommodation centres, private houses, flats, hotels, or other premises. ${ }^{127}$ The Directive, however, remains rather evasive on the question of standards and only stipulates that accommodation centres must guarantee "an adequate standard of living" 128 and that other forms of housing must be "adapted for housing applicants." ${ }^{129}$ Irrespective of the elected type of accommodation, Member States are under the obligation to protect asylum seekers' right to family life as well as ensure communications with relatives, UNHCR representatives, and NGOs. ${ }^{130}$ Notwithstanding its positive aspects, the major weakness of the Reception Conditions Directive with regard to accommodation lies with its failure to establish clear standards designed to ensure that asylum seekers are lodged in conditions conducive to a "dignified standard of living," one of the stated aims of the Directive. ${ }^{131}$

Another determinant of "a dignified standard of living" is access to health care. The Reception Conditions Directive requires that health care be provided and include, as a minimum, emergency and essential treatment. ${ }^{132}$ The Commission's Proposal was more comprehensive and provided for access to primary health care and psychological care that could not be postponed. ${ }^{133}$

UNHCR indicated that these minimum standards should include counselling on reproductive health; confidentiality in respect of medical and psychological counselling; psychological counselling free of charge and training regarding sensitivity for medical personnel dealing with patients of different cultural backgrounds. ${ }^{134}$

One may regret the absence of more wide-ranging and specific minimum standards designed to ensure the full realization of the right to health care for asylum seekers. ${ }^{135}$

The Reception Conditions Directive provides for the schooling and education of minor children of asylum seekers as well as minors who are asylum seekers themselves. ${ }^{136}$ The Directive stipulates, inter alia, that education be provided in accommodation centres. ${ }^{137}$ UNHCR expressed concern that this "segregation" would contribute to the marginalization of these children. It recommended that where such arrangements were in place, they should only be for a limited period. ${ }^{138}$

While there are positive aspects to the Reception Conditions Directive, the level of compromise required for its adoption, which transpires in the degree of discretion granted to the EU Member States, prevents the Directive from reflecting best practice and establishing standards that fully embrace international law.

The avoidance of conflict between the EU legal regime and the international instances may well depend on how the [European] Court of Justice takes up its task in interpreting the asylum measures [including the Reception Conditions Directive] in the context of the Member States international human rights obligations. ${ }^{139}$

\section{Conclusion}

Restrictive asylum policies tend to use the threat of destitution as a deterrent against asylum seeking. Such practices rest upon the simplistic and erroneous assumption that the level of support in host States is a key factor in asylum seekers' primary and secondary movement patterns. Furthermore, sentencing asylum seekers to a destitute life undermines the right to seek refugee status and goes against international human rights standards.

Developments at EU level reveal stern and worrying tensions between the EU Member States' obligations under international refugee and human rights law and the EU objectives in the field of asylum. While commitment to human rights and refugee protection is relentlessly reiterated, Member State and EU policies and legislation on asylum show a different picture. The drive towards reducing the numbers of asylum seekers in the EU has pushed the question of human right into the background. This state of affairs is made worse by the fact that asylum is increasingly perceived as a migration and security-related matter; this 
contributes to the creation of a climate hostile to asylum seekers.

The challenge for the enlarged EU is therefore to uphold the right to seek refugee status and remain true to its role and image as a human rights champion. To deny asylum seekers dignified living conditions would amount to repudiating the European humanitarian tradition and condoning breaches of international law within but also beyond the territory of the EU. The challenges faced by the EU Member States as host countries must not be overlooked; however, they cannot be used to legitimize unduly austere laws and to justify violations of international norms. The move towards a common European asylum system provides the EU with a critical opportunity to revisit its asylum policy with a view to reconciling EU legislation with international refugee and human rights law.

\section{Notes}

1. Ligue des Droits de l'Homme, L'Actualité, "Il Fait Beau. Ce n'est pas une Raison pour Laisser les Demandeurs d'Asile à la Rue," <http://www.ldh-france.org/actu_nationale.cfm?i dactu $=703>$ (date accessed:online: November 2, 2004).

2. Sylvie Da Lomba, The Right to Seek Refugee Status in the European Union (Antwerp, Oxford, andNew York: Intersentia, 2004) at 107.

3. Colin Harvey, "The Right to Seek Asylum in the European Union" (2004) 1 European Human Rights Law Review 17-36.

4. The French Commission Nationale Consultative des Droits de l'Homme $(\mathrm{CNCDH})$ voiced its concern and disappointment following the conclusions reached by the European Council at its summit in Laeken in December 2001. The CNCDH criticized the EU for bringing asylum under the umbrella of migration, thus eroding the autonomy of the former to the detriment of international protection. (Ligue des Droits de l'Homme, L'Actualité, "Sur la Déclaration Européenne de Laeken relative à la Politique Commune d'Asile et d'Immigration," online: <http://www.ldh-France.org/actu_nationale. cfm?idactu $=446>$ (date accessed: November 2, 2004).

5. Convention relating to the Status of Refugees, 28 July 1951, 189 U.N.T.S. 150 [Refugee Convention].

6. UNHCR, “A 'Timeless' Treaty Under Attack: Reconsidering the Convention," online: <http://www.unhcr.ch/1951convention/ reconsidering.html> (date accessed: November 5, 2004).

7. This is, for instance, the case of persons subject to the temporary protection regime. See Council Directive 2001/55/EC of 20 July 2001 on minimum standards for giving temporary protection in the event of a mass influx of displaced persons and on measures promoting a balance of efforts between Member States in receiving such persons and bearing the consequences thereof, O.J.E.C. L 212/12, 7.8.2001.

8. Council Directive 2003/9/EC of 27 January 2003 laying down minimum standards for the reception of asylum seekers, O.J.E.U. L 31/28, 6.2.2003 [Reception Conditions Directive].
9. Oscar Schachter, "Human Dignity as a Normative Concept" in Henry Steiner and Philip Alston, $2^{\text {nd }}$ ed., International Human Rights in Context: Law, Politics and Morals (Oxford: Clarendon Press, 2000) at 400.

10. Keith D. Ewing, "Social Rights and Constitutional Law" (1999) Public Law 104-23.

11. Sylvie Da Lomba, "Fundamental Social Rights for Irregular Migrants: The Right to Health Care in France and in England" in Barbara Bogusz, Ryszard Cholewinski, Adam Cygan, and Erika Szyszczak, eds, Irregular Migration and Human Rights: Theoretical, European and International Perspectives (Leiden and Boston: Martinus Nijhoff, 2004) at 364.

12. Ibid.

13. Andrew Geddes, Immigration and European Integration: Towards Fortress Europe? (Manchester and New York: Manchester University Press, 2000) at 153.

14. Council Directive 2003/109/EC of 25 November 2003 concerning the status of third-country nationals who are long-term residents, O.J.E.U. L 16/44, 23.1.2004. The EU Member States must implement the Directive by 23 January 2006 (ibid., art. 26).

15. Teresa Hayter, Open Borders: The Case against Immigration Controls (London and Sterling, VA: Pluto Press, 2000) at 105-12.

16. UNHCR Executive Committee, Conclusion on reception of asylum-seekers in the context of individual asylum systems, Conclusion No. 93 (LIII) - 3002, online: <http://www.unhcr.ch/ cgi-bin/texis/vtx/home/+xwwBmaeyCEpwwwwnwwwww wwhFqh0kgZTtFqnnLnqAFqh0kg ZTcFq FGnqnpBodDadhaw5Oc1Me2zxxnAnG5Dzmxwwwwwww/opendoc.htm> (date accessed: November 2, 2004).

17. Supra note 15 at $105-12$.

18. Ibid.

19. UNHCR, Reception of Asylum-Seekers, Including Standards of Treatment, in the Context of Individual Asylum Systems, EC/GC/01/17, 4 September 2001.

20. Ibid., para. 7

21. Ligue des Droits de l'Homme, "L'Accueil Humanitaire Ne Suffit Pas!" online: <http://www.ldh-France.org/actu_nationale.cfm?idactu $=416>$ (date accessed: November 2, 2004).

22. R. (Q and others) v. Secretary of State for the Home Department, Judgment of February 19, 2003, [2003] EWHC 195 (Admin), para. 72. Infra note 62.

23. UK Refugee Council, Hungry and Homeless: The Impact of the Withdrawal of State Support on Asylum Seekers, Refugee Communities and the Voluntary Sector (London: Refugee Council, April 2004) at 28. The Refugee Council looked into the impact of Section 55 of the Nationality, Immigration and Asylum Act 2002 (c. 41) (NIA Act 2002). Section 55 is examined later in the paper.

24. On the implication of the enlargement of the EU for its asylum policy, see Rosemary Byrne, Gregor Noll, and Jens VedstedHansen, eds., New Asylum Countries? Migration Control and Refugee Protection in an Enlarged European Union (The Hague, London, and New York: Kluwer Law International, 2002).

25. Supra note 2 at 221 and supra note 15 at 105-12. 
26. Supra note 23 , s. 55(1).

27. The compatibility of Section 55 with the ECHR was contested before English courts. The English case law on Section 55 is examined later in the paper.

28. Dallal Stevens, UK Asylum Law and Policy, Historical and Contemporary (London: Sweet and Maxwell, 2004) at 256-57.

29. Home Office Press Release, "New Measures to Cut Asylum Abuse Come into Force," July 8, 2003, reproduced in ibid. at 257.

30. Supra note 19 , paras. $20-23$.

31. Supra note 2 at 219.

32. Supra note 19, para. 4. The right to an adequate standard of living is enshrined in the Universal Declaration of Human Rights, 10 December 1948, UNGA Resolution 217 A(III) $[U D H R]$, art. 25(1) and in the International Covenant on Economic, Social and Cultural Rights, 16 December 1966, UNGA Resolution 2200A (XXI) [ICESCR], art. 11(1).

33. Ibid., art. 25(1) UDHR and art. 12(1) ICESCR.

34. Ibid. Right to health care: art. 25(1) UDHR and art. 12(1) ICESCR; Right to education: art. 26(1) and (2) UDHR and art. 13(1) and (2) ICESCR.

35. Convention on the Elimination of all Forms of Discrimination Against Women, 18 December 1979, UNGA Resolution 34/180 $[C E D A W]$, in particular art. 12 (right to health care).

36. Convention on the Rights of the Child, 12 December 1989, UNGA Resolution 44/25 [CRC], in particular art. 22 (right to protection and humanitarian assistance for children who seek refugee status or are refugees, whether unaccompanied or accompanied), art. 24 (right to health, including the right to health care), art. 27(1) (right to an adequate standard of living) and art. 28 (right to education).

37. Supra note 32, art. 2(1).

38. Sylvie Da Lomba, "Particular Issues of Public Health: Refugees" in Robyn Martin and Linda Johnson, eds., Law and the Public Dimension of Health (London and Sydney: Cavendish Publishing, 2001) at 187.

39. Supra note 32 , art 5.

40. International Covenant on Civil and Political Rights, 16 December 1966, UNGA Resolution 2200A (XXI) [ICCPR].

41. Convention for the Protection of Human Rights and Fundamental Freedoms, 4 November 1950, CETS No. 005 [ECHR].

42. Supra note 23.

43. HL Deb. Vol. 639, October 24, 2002, col. 1470.

44. Supra note 28.

45. Pursuant to Section 55(5)(a) to (c) of NIA Act 2002 (supra note 23), asylum seekers will not have their eligibility for National Asylum Support Service (NASS) if they:

- have dependent children under the age of eighteen;

- are visibly pregnant;

- have special needs (if needs do not arise solely out of destitution or effects of destitution, local authorities are responsible for care arrangements);

- applied for asylum in-country due to changed conditions in their country of origin and proved that they have applied at the earliest opportunity following the change of circumstances.

46. R. (Q and others) v. Secretary of State for the Home Department, Judgment of March 18, 2003 [2003] EWCA Civ 364.

47. Supra note 28 at $201-02$.

48. Supra note 22.

49. Ibid., paras. 62-67.

50. Supra note 46, para. 56.

51. Asylum seekers cannot work in the UK (Asylum and Immigration Act 1996, c. 49, s. 8), unless the Home Secretary gives them special permission to do so (Immigration (Restrictions on Employment) Order 1996).

52. Supra note 46 , para 57.

53. Ibid., para. 59; also, Immigration and Asylum Act 1999, c. 33.

54. Ss. 44(2) and 44(6) NIA Act 2002 (supra note 22), inserting new s. 95(2) and (3) Immigration and Asylum Act 1999 (supra note 53).

55. Prettyv. UK (2002) 35 EHHR 1.

56. Ibid., para. 52.

57. Supra note 22, para. 66.

58. Supra note 46 , paras. 62-63.

59. Ibid., para. 63.

60. Ibid., para. 119(iii).

61. Ibid., paras. 62-63.

62. Supra note 22, para. 72.

63. Bensaid v. UK (2001) 33 EHRR 205, para. 46.

64. Supra note 46, para. 64.

65. Ibid.

66. Supra note 41. Article 8(2) of the ECHR reads:

There shall be no interference by a public authority with the exercise of this right except such as is in accordance with the law and is necessary in a democratic society in the interests of national security, public safety or the economic well-being of the country, for the prevention of disorder or crime, for the protection of health or morals, or for the protection of the rights and freedoms of others.

67. Supra note 28 at 338.

68. Supra note 46, para. 116.

69. Ibid., paras. 85-86, 94, and 98-99.

70. R. v. Secretary of State for the Home Department, ex parte $S, D$ $\& T$, judgment of July 31, 2004, [2003] EWHC 1941 (Admin), para. 19.

71. Supra note 28 at 339.

72. The Secretary of State for the Home Department v. Wayoka Limbuela, Binyam Tefera Tesema, Yusif Adam, Judgment of May 21, 2004 [2004] EWCA Civ 540 CA; $R$ (Limbuela) $v$. Secretary of State, Judgment of February 4, 2004 [2004] EWHC 219 (Admin) QBD; R (Tesema) v. Secretary of State, Judgment of February 16, 2004 [2004] EWHC 295 (Admin) QBD (Admin $\mathrm{Ct}) ; R$ (Adam) v. Secretary of State, Judgment of February 17, 2004 [2004] EWHC 354 (Admin) QBD (Admin Ct).

73. UK Refugee Council, "Asylum Seekers Win Back Their Rights to Basic Food," June 25, 2004, online: <http://www.refugee- 
council.org.uk/news/june04/relea171.htm> (date accessed: November 12, 2004). On that occasion, the Secretary of State decided against challenging the ruling of the Court of Appeal in the High Court.

74. Charter of Fundamental Rights of the EU, O.J.E.C. C 364/1, 18.12.2000 [EU Charter].

75. Ibid. Article 18 of the EU Charter stipulates: "The right of asylum shall be guaranteed with due respect for the rules of the Geneva Convention of 28 July 1951 and the Protocol of 31 January 1967 relating to the Status of Refugees in accordance with the Treaty establishing the European Community." Whilst the wording of the EU Charter is prima facie rather generous (for instance, the UDHR only recognizes "a right to seek and to enjoy in other countries asylum from persecution," supra note 32, art. 14), it only pays "due respect" to the Refugee Convention and the Refugee Protocol (Protocol relating to the Status of Refugees, 31 January 1967, 606 U.N.T.S. 267) (supra note 74 , art. 18). Moreover, the right to asylum set out in Article 18 is construed within the constraints of the Treaty establishing the European Community (ibid). On this issue, see, inter alia, Steve Peers, "Immigration, Asylum and the European Union Charter of Fundamental Rights" (2001) 3 European Journal of Migration and Law 141-69.

76. Supra note 74 , art. 34 .

77. Ibid., art. 35.

78. Ibid., art. 14.

79. Ibid., art. 24.

80. Ian Rogers, "From the Human Rights Act to the Charter: Not Another Human Rights Instrument to Consider" (2002) 3 European Human Rights Law Review 343-56, at 343.

81. Supra note 28 at 426 ; see also supra note 75 at 167.

82. Treaty establishing a Constitution for Europe, signed in Rome on October 29, 2004 [EU Constitution] Part II. The EU Constitution will enter into force upon ratification by all the EU Member States.

83. Tampere European Council, Presidency Conclusions, October 15 and 16, 1999, online: <http://europa.eu.int/council/off/ conclu/oct99_en.htm> (date accessed: November 3, 2004).

84. Emphasis added.

85. Supra note 83 , para. 14 . "In the longer term, Community rules should lead to a common asylum procedure and a uniform status for those who are granted asylum valid throughout the Union (... )." (Ibid., para. 15).

86. Supra note 8.

87. The Reception Conditions Directive must be implemented in the Member States by February 6, 2005 (ibid., art. 26).

88. UNHCR, "European Union: Reception Conditions Directive," online: <http://www.unhcr.ch/cgi-bin/texis/vtx/home/ + dwwBmjsezYmwwwwAwwwwwwwhFqnN0bItFqnDni5A FqnN0bIcFq0Gn qnpBodDaqdDmoBodD5amoGnqBo VnDzmxwwwwwww/opendoc.htm $>$ (date accessed: November 2, 2004).

89. Supra note 2 at 221.

90. Ibid.

91. Supra note 8 , art. 4 .
92. It is important to stress that most asylum seekers are unaware of the reception standards in force in the various Member States. Moreover, particularly when at the hands of traffickers in human beings, asylum seekers may be denied a say in the choice of countries of destination. Such considerations should be factored into analyses of the causes for asylum seekers' secondary as well as primary movements within the EU.

93. Commission Proposal for a Council Directive laying down minimum standards on the reception of applicants for asylum in Member States, $\operatorname{COM(2001)~} 181$ final.

94. Supra note 74.

95. Supra note 8, art. 3(1). However, the Reception Conditions Directive does exclude from its personal scope Member State nationals (ibid.). The premise for this exclusion is the presumed safety of the Member States.

96. Ibid., art. 2(c).

97. Ibid.

98. Ibid., art. 2(d). Contrast with the definition of the term "family member" adopted by the Commission in its Proposal, which included "other members of the family if they are dependent on the applicant or have undergone particularly traumatic experiences or require special treatment," such as grandchildren, grandparents, great-grandparents, or other adults depending on other family members (supra note 93, art. 2(d)(iii)).

99. See, for instance, UNHCR, "Handbook on Procedures and Criteria for Determining Refugee Status" (Geneva: UNHCR, 1979), para. 189

100. Supra note 8 , art. 17(1).

101. Ibid.

102. Ibid.

103. Ibid., art. 13(3).

104. Ibid., art. 13(4).

105. Ibid., art. 16(1)(a).

106. Ibid.

107. Ibid.

108. Ibid., art. 16(1)(b).

109. Ibid., art. 16(2)

110. See discussion on Section 55 of the INA Act 2002.

111. Supra note 23.

112. Supra note 8 , art. 16(2).

113. Ibid., art. 16(4).

114. Ibid., art. 21(1).

115. Ibid., art. 11(1).

116. Ibid. art. 11(2).

117. Supra note 93, art. 13(1).

118. Elspeth Guild, "Seeking Asylum: Storm Clouds between International Commitments and EU Legislative Measures" (2004) 29 European Law Review 198-218 at 214.

119. Supra note 8, art. 11(4).

120. Supra note 88.

121. Supra note 2 at 229.

122. Supra note 8 , art. 13(2).

123. Ibid.

124. Supra note 93. 
125. Supra note 2 at 232 .

126. Ibid.

127. Supra note 8 , art. 14(1)(b) and (c).

128. Ibid., art. 14(1)(b).

129. Ibid., art. 14(1)(c).

130. Ibid., art. 14(2)(a) and (b).

131. This was one of the expressed aims of the Reception Conditions Directive (Ibid., recital 7 of the preamble to the Directive).

132. Ibid., art.15(1).

133. Supra note 93, art. 20(1)(a) and (b).

134. Supra note 118 at 216.

135. The right to health care, which forms part of the right to health, is enshrined in a number of international human rights instruments the personal scope of which may cover asylum seekers (e.g. art. 25 UDHR, supra note 32; art. 12 ICESCR, ibid.; CEDAW art. 12, supra note 35; and CRC art. 24(1), supra note 36$)$.

136. Supra note 8 , art. 10(1).

137. Ibid.

138. Supra note 118 at 214 . On the issue of access to education for asylum seekers, see supra note 2 at $240-43$.

139. Supra note 118 at 218 .

Sylvie Da Lomba, Ph.D., is a Lecturer in Law at the Faculty of Law of the University of Leicester, UK. 